Arq. Bras. Med. Vet. Zootec., v.67, n.2, p.325-333, 2015

\title{
Chondroitin sulfate and glucosamine in the cartilage and subchondral bone repair of dogs - Histological findings
}

[Sulfato de condroitina e glucosamina na reparação da cartilagem e do osso subcondral de cães - Achados histológicos]

\author{
R.B. Eleotério ${ }^{1}$, K.C.S. Pontes ${ }^{2}$, J.P. Machado ${ }^{2}$, E.C.C. Reis ${ }^{3}$, P.S. Ferreira ${ }^{4}$, M.B. Silva ${ }^{3}$, \\ N.J.S. Martins ${ }^{5}$, N.A. Fernandes ${ }^{3}$, A.P.B. Borges ${ }^{3} *$ \\ ${ }^{1}$ Aluno de pós-graduação - Universidade Federal de Viçosa - UFV - Viçosa, MG \\ ${ }^{2}$ FACISA-Univiçosa - Viçosa, MG \\ ${ }^{3}$ Universidade Federal de Viçosa - UFV - Viçosa, MG \\ ${ }^{4}$ Programa de residência - Universidade Federal Rural do Rio de Janeiro, RJ \\ ${ }^{5}$ Médico veterinário autônomo
}

\begin{abstract}
Chondroitin and glucosamine sulfate nutraceuticals are commonly used in the management of degenerative articular disease in veterinary routine. However, there are controversies on the contribution of these substances to articular cartilage. The purpose of this study was to evaluate the efficiency of a chondroitin and glucosamine sulfate-based veterinary nutraceutical on the repair of an induced osteochondral defect in a dog femoral condyle, by macroscopic, histological and histomorphometric analyses. The nutraceutical was orally administered the day following injury induction, every 24 hours (treated group, TG, $\mathrm{n}=24$ ), compared with animals that did not receive the product (control group, CG, $\mathrm{n}=24$ ). Six animals per group were anaesthetized for sample collection at 15, 30, 60 and 90 days after surgery. At 15 days, defects were macroscopically filled with red-pinkish tissue. After 30 days, whitish color tissue was observed, both in TG and CG animals, with firmer consistency to touch at 60 and 90 postoperative days. Histological analysis demonstrated that, in both groups, there was initial blood clot formation, which was subsequently substituted by a fibrin net, with capillary proliferation from the adjacent bone marrow and infiltration of mesenchymal cells in clot periphery. As cellular differentiation developed, repair tissue presented a fibrocartilage aspect most of the time, and new subchondral bone formation occurred in the deepest area corresponding to the defect. Histomorphometry suggested that the nutraceutical did not favor the articular cartilage repair process. It was concluded that nutraceutical did not significantly influence chondrocytes proliferation or hyaline architecture restoration.
\end{abstract}

Keywords: degenerative articular disease, osteoarthritis, arthrosis, chondroprotective, cartilage

\section{RESUMO}

Os nutracêuticos compostos de sulfato de condroitina e glucosamina são comumente utilizados no manejo da doença articular degenerativa na rotina veterinária. Entretanto, existem controvérsias sobre a contribuição dessas substâncias à cartilagem articular. O objetivo deste trabalho foi avaliar a eficácia de um nutracêutico veterinário à base de sulfato de condroitina e glucosamina na reparação de defeitos osteocondrais induzidos no côndilo femoral de cães, através de análises macroscópica, histológica e histomorfométrica. O nutracêutico foi administrado no dia seguinte à indução da lesão, pela via oral, a cada 24 horas (grupo tratado - GT, 24 animais), sendo comparado a animais que não receberam o produto (grupo controle - GC, de igual número de animais). Aos 15, 30, 60 e 90 dias após a cirurgia, seis animais por grupo foram anestesiados para ser realizada a coleta das amostras. Aos 15 dias, os defeitos eram macroscopicamente preenchidos por tecido de coloração rósea a avermelhada. Já a partir dos 30 dias, observou-se preenchimento por tecido de coloração esbranquiçada, tanto nos animais do GT

Recebido em 31 de julho de 2013

Aceito em 7 de agosto de 2014

* Autor para correspondência (corresponding author)

E-mail: andrea@ufv.br 
quanto nos do GC, com consistência mais firme ao toque digital aos 60 e 90 dias de pós-operatório. A análise histológica revelou que, em ambos os grupos, houve inicialmente formação de coágulo sanguíneo que, posteriormente, foi substituído por uma rede de fibrina, com proliferação de capilares a partir da medula óssea adjacente e infiltração de células mesenquimais na periferia do coágulo. À medida que se processou a diferenciação celular, o tecido de reparação se apresentou na maioria das vezes com aspecto de fibrocartilagem e, na região mais profunda da área correspondente ao defeito, ocorreu formação de osso novo subcondral. A histomorfometria sugeriu que o nutracêutico não favoreceu o processo de reparação da cartilagem articular. Concluiu-se que o nutracêutico não influenciou consideravelmente na proliferação de condrócitos nem na restauração da arquitetura hialina.

Palavras-chave: doença articular degenerativa, osteoartrite, artrose, condroprotetor, cartilagem

\section{INTRODUCTION}

Chondroprotectives are products composed by similar agents to cartilaginous matrix components and have been widely employed in the treatment of degenerative articular disease (DAD) in veterinary medicine. It is believed that they have antiinflammatory action and are able to reduce proteoglycans and collagen loss by inhibition of cartilage degrading enzymes, besides having stimulatory action on the synthesis of these same substances, promoting increase in chondrocytes and matrix proliferation (Clark, 1991).

Some studies demonstrated that chondroprotectives can be important in the control of pathological alterations of cartilage and can complement DAD treatment both in veterinary (Clark, 1991; Biasi et al., 2005; Arafa et al., 2013) and in human subjects (Nakasone et al., 2011; Kanzaki et al., 2012). Glucosamine and chondroitin sulfate stand out among the substances with chondroprotective properties, (Vaughan-Scott and Taylor, 1997).

It is considered that glucosamine and chondroitin sulfate administered orally as nutraceuticals can be absorbed by the gastrointestinal tract and reach the articular cartilage. However, the biochemical details of this therapeutic option are still not completely understood and further investigation is necessary (Blitterswijk et al., 2003), as the degenerative process has not been satisfactorily prevented or delayed yet (Melo et al., 2008).

The use of these products becomes controversial in face of previous studies (Sawitzke et al., 2010; Miller and Clegg, 2011). These authors raise questions on the methodology and results of studies attesting the benefits associated to the administration of nutraceutical chondroprotectives in human patients with DAD. Wandel et al. (2010) concluded that authorities and health plans should not cover costs of treatments with chondroitin and glucosamine sulfate, and that the prescription of these substances for human patients who have not received this type of treatment yet must be discouraged.

According to Hall (2012), the scientific evidences do not justify the importance given by Sinusas (2012) to the use of chondroitin and glucosamine as one of the main treatments for osteoarthritis. Additionally, Hall (2012) concludes that the reasonable basis for the prescription of these substances is suspicious, since they are already produced by the organism in such a way that the quantity provided by the intake of nutraceuticals only represents a small fraction of the already existing one. In addition, these authors affirmed that chondroitin and glucosamine are not essential nutrients as vitamins, which can make a significant difference even in small quantities.

Thus, the purpose of this study was to evaluate the efficiency of a commercially available veterinary nutraceutical, chondroitin and glucosamine sulfatebased in the repair of a experimentally induced osteochondral defect in the dog's lateral femoral condyle by macroscopic, histological and histomorphometric analyses.

\section{MATERIAL AND METHODS}

The experimental study was approved (process number 18/2008) by the Ethics Committee of the Veterinary Department of the Federal University of Viçosa (DVT/UFV, Viçosa, MG, Brazil). The principles for animal use in teaching, research and testing of the DVT/UFV were rigorously followed.

Forty-eight adult mixed breed dogs weighting between 10 and $25 \mathrm{~kg}$, originating from the experimental kennel of the DVT/UFV were used. All animals were considered adults by radiographic skeletal evaluation.

Animals were randomly distributed in four observation periods (T15, T30, T60 and T90), 
each one containing 12 animals. Animals from each period were subdivided in two groups of equal number: TG, treated group; $\mathrm{CG}$, control group. Table 1 shows the experimental groups.

Table 1. Experimental groups, number of animals per group and post-operatory periods

\begin{tabular}{llc}
\hline Group & Number of animals & $\begin{array}{l}\text { Post-operatory } \\
\text { periods }\end{array}$ \\
\hline T15 & 12 (6 TG and 6 CG) & 15 days \\
T30 & $12(6$ TG and 6 CG) & 30 days \\
T60 & 12(6 TG and 6 CG) & 60 days \\
T90 & $12(6$ TG and 6 CG) & 90 days \\
\hline
\end{tabular}

T15: Group with 15 postoperative days; T30: Group with 30 postoperative days; T60: Group with 60 postoperative days; T90: Group with 90 postoperative days; TG: Subgroups treated with chondroitin and glucosamine sulfate; CG: Control subgroups. Source: Eleotério et al. (2012).

For the surgical procedure, dogs were submitted to 12-hour water and food fast. Subsequently, they were tranquilized with acepromazine $(0.1 \mathrm{mg} / \mathrm{kg}$, intravenously, Acepran, Univet, Brazil), anesthetized initially with propofol $(7 \mathrm{mg} / \mathrm{kg}$, intravenously Propovan, Cristália, Brazil) and kept with isoflurane (Isoforine, Cristália, Brazil) diluted in $100 \%$ oxygen. The animal was placed in left side decubitus position and the surgical field was properly prepared. A $6 \mathrm{~mm}$ diameter osteochondral defect was created in the lateral right femoral condyle (Figure 1), as proposed by Eleotério et al. (2012).

The animals received morphine $(0.3 \mathrm{mg} / \mathrm{kg}$, intramuscular administration, Dimorf, Cristália, Brazil) immediately post-surgery for extra days, every 12 hours. All TG animals received chondroprotective nutraceutical daily from the first postoperative day (beginning of treatment) until completion of the treatment period for each group. The nutraceutical chondroprotective used was acquired directly from the pharmaceutical laboratory in palatable tablets form, containing $200 \mathrm{mg}$ chondroitin sulfate, $300 \mathrm{mg}$ glucosamine, $24 \mathrm{mg}$ aromatizer and $1200 \mathrm{mg}$ vehicle excipient q.s., as specified on the product label. According to product recommendations, one tablet was administered every 24 hours to dogs weighting up to $10 \mathrm{~kg}$ of body weight, two tablets to dogs with 11 to $20 \mathrm{~kg}$ and four tablets to dogs with 21 to $30 \mathrm{~kg}$. The tablets were administered by the same person, directly in the oropharynx of the dogs and the time required to observe complete swallowing was respected.

Samples containing the osteochondral defects were collected at the end of the observation period of each experimental group. For samples collection, the same surgical access described for the osteochondral defect was followed. A cylindrical fragment corresponding to the defect area was collected using an $8 \mathrm{~mm}$ diameter trephine drill coupled to a motorized handpiece (Black and Decker, RT650KA, Brazil). The collected fragment was removed by lever movement using a dental instrument. After fragment removal, suture of soft tissues and similar postoperative treatment to that described for injury induction were performed. Samples were macroscopically analyzed regarding filling (both in height and in extension) and aspect of present tissue. Following, the samples were fixed in $10 \%$ buffered formaldehyde for 24 hours, and stored in $70 \%$ alcohol until histological processing with hematoxylin and eosin staining (H\&E) for histological analysis in light microscope.

Photomicrographs of histological sections were obtained using a light microscope coupled to a digital camera. Quantifications of tissue and cell types were carried out using the Image Pro Plus (Media Cybernetics, Inc, USA) software. The histomorphometry data were submitted to nonparametric Mann-Whitney`s test at 5\% significance level.

\section{RESULTS}

Osteochondral defects were macroscopically filled by a red-pinkish tissue in animals from T15 group. The tissue was less consistent to touch than that of the not injured cartilage, both in TG and in CG. Besides, the adjacent cartilage edges to the defect presented abnormalities and slits. Upon histological examination, the defect was partially filled by loose connective tissue (Figure 2A), characterized by fibers oriented parallel to the articular surface and cells originating from the bone marrow (Figure 2B). At the defect bottom, blood vessels, mesenchymal chondrocyte-like cells and numerous osteoclasts were observed (Figure 2C). 


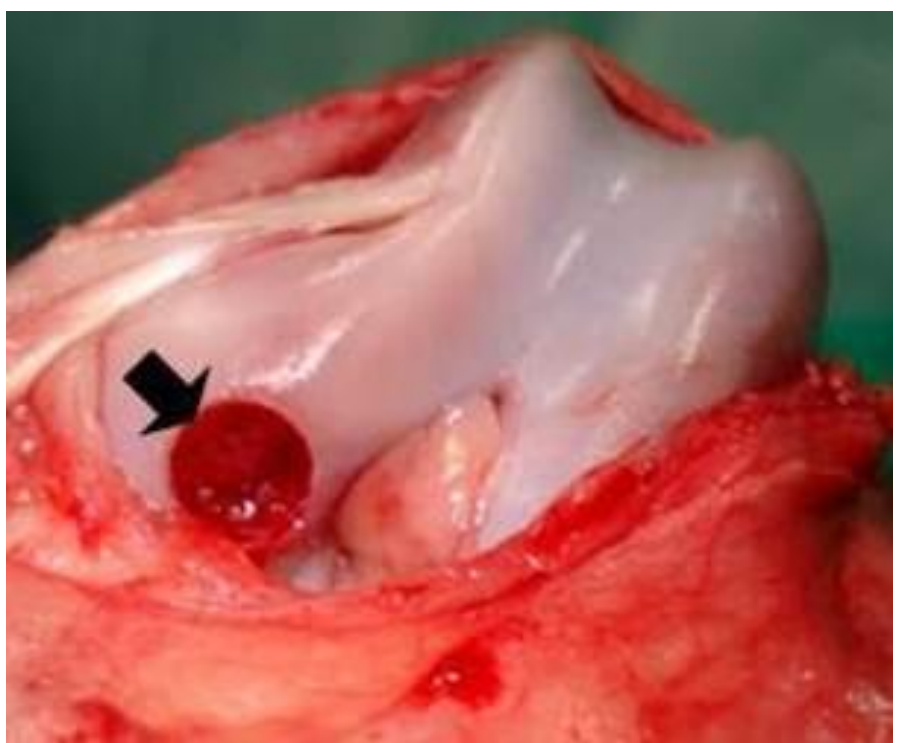

Figure 1. Dog. Photograph illustrating the right femoral condyle after osteochondral injury creation. Note circular injury without cartilage (arrow) containing blood from the subchondral bone.
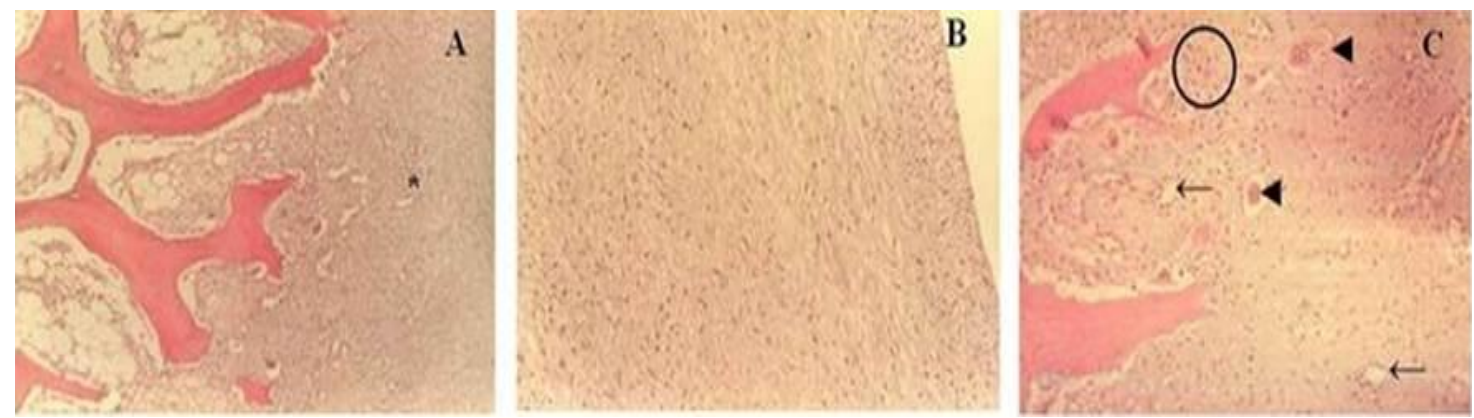

Figure 2. Photomicrographs illustrating repair tissue of osteochondral defect in lateral femoral condyle in a dog at the end of T15. (A) Presence of loose connective tissue (*), H\&E, 100x. (B) Detail of the loose connective tissue, H\&E, 200x. (C) Blood vessels (arrow), mesenchymal chondrocyte-like cells (circle) and osteoclasts (arrowhead) at subchondral region, H\&E, 200x.

In the macroscopic analysis at the end of T30 the surgical center defect was filled with a whitish tissue, both in TG and CG animals. This filling was considered partial in both groups, as new tissue occupied the defect bottom, but not equal to the height of the not injured adjacent cartilage. Only in one TG animal the total filling of the area corresponding to the defect was observed, where a whitish newly formed tissue developed and was equal to the height of the adjacent cartilage. Even in this case of total filling it was still possible to macroscopically observe a circular line that delimited the edges of the injured area. Microscopically, the repair tissue filling the defects created in T30 animals was constituted of fibrocartilage (Figure 3A), in which extracellular matrix fibers were distributed parallel to the articular surface (Figure 3B). In the region corresponding to the defect bottom, subchondral bone formation was observed by differentiation of mesenchymal cells exhibiting chondrocyte aspect and isogenous groups close to blood vessels, with consequent beginning of new subchondral bone formation (Figure 3C and 3D).

Macroscopically, it was observed that the tissue filling the defect at the end of T60 also presented a whitish color, similar to that found in T30. Although it did not reach the height of the noninjured adjacent cartilage, this tissue presented higher growth and firmer consistency to touch than that observed in T30 biopsies, showing macroscopic aspect similar to that of the hyaline 
cartilage in T60 samples. In only one animal in $\mathrm{CG}$, the repair tissue developed and reached the adjacent cartilage height, and it was also possible to delimit defect edges. In addition, in the macroscopic analysis, adherence of synovial membrane to the repair tissue was identified in one TG animal. Although macroscopically similar to the hyaline cartilage, the histological analysis showed that defects were also predominantly filled by fibrocartilaginous tissue both in the TG and in CG, as observed in T30. Most of the regions containing chondrocyte cells and isogenous groups exhibited an ossification process in the deepest defect region, providing better organization pattern of subchondral bone trabeculae in comparison with that found in T30. Additional histological findings included the presence of fibrocytes, blood vessels and chondrocytes with a degeneration aspect.

Samples from T90, both in TG and in CG, showed defect filled by a whitish to yellowish tissue, with similar consistency to touch of the adjacent non-injured cartilage. In five TG animals this repair tissue developed and reached the adjacent cartilage height, which was only observed in two CG animals. As well as in previous treatments, it was still possible to delimit the defect edges. Histological analysis of biopsies containing the defect showed that the repair tissue surface of T90 animals was also predominantly constituted by fibrocartilage (Figure 4A), which developed both in TG and in CG. In the deepest region there was formation of new subchondral bone, which presented an organization pattern superior to that observed in previous treatments, in such a way that it was possible to notice a continuous area of already formed subchondral bone (Figure 4B). However, at higher magnification it was noticed that subchondral new bone formation had not been concluded, since it was still possible to identify regions undergoing ossification diffused in the already formed bone tissue (Figure 4C). The presence of a non-continuous calcification line (Figure 5A) and cells with large and round nucleus (chondrocytes) in the trabecular structure (Figure 5B), indicated that calcium deposition had not occurred on the cartilagenous substrate preceding bone formation. This confirms the hypothesis that formation and subchondral bone reorganization had not been completed at 90 postoperative days in both groups. Still regarding the histological analysis of T90, development of fibrocartilage on the surface and hyaline cartilage in the center of the defect was noticed in one TG animal. However, this hyaline tissue presented degeneration aspects such as nuclear pyknosis and empty lacunae (Figure 5C).

Additionally, the histological analysis allowed the identification of the repair tissue composition to then estimate the percentage of each component by histomorphometric analysis. In $\mathrm{T} 15$, percentages of structures as young and mature fibroblasts (fibrocytes), blood vessels, chondrocyte-like mesenchymal cells, osteoclasts, loose connective tissue fibers and subchondral bone reabsorption areas were estimated so that non-parametric Mann-Whitney test indicated no significant difference in the percentages between TG and CG. In T30, the quantified structures were young and mature fibroblasts (fibrocytes), blood vessels, osteoclasts, extracellular matrix of fibrocartilaginous tissue, subchondral bone formation areas and chondrocytes with and without degeneration aspect, obtaining significant difference between groups only for the percentage of chondrocytes without degeneration aspect $(\mathrm{p}=0.03)$, evidencing that treated group animals (TG) presented, on average, lower percentage value of chondrocytes than the control group (CG). In T60 and T90 percentages for blood vessels, chondrocytes without degeneration aspect, extracellular matrix of fibrocartilaginous tissue, new subchondral bone formation and apparently degenerated chondrocytes were estimated. In T60 samples a significant difference was observed between groups only for new subchondral bone percentage $(p=0.04)$, indicating that TG group animals presented, on average, higher percentage value of newly formed subchondral bone than those of CG. In T90 no significant difference was observed for the percentage of structures between groups.

Except for some particularities, the main stages characterizing the repair process showed similarity between TG and CG animals. 

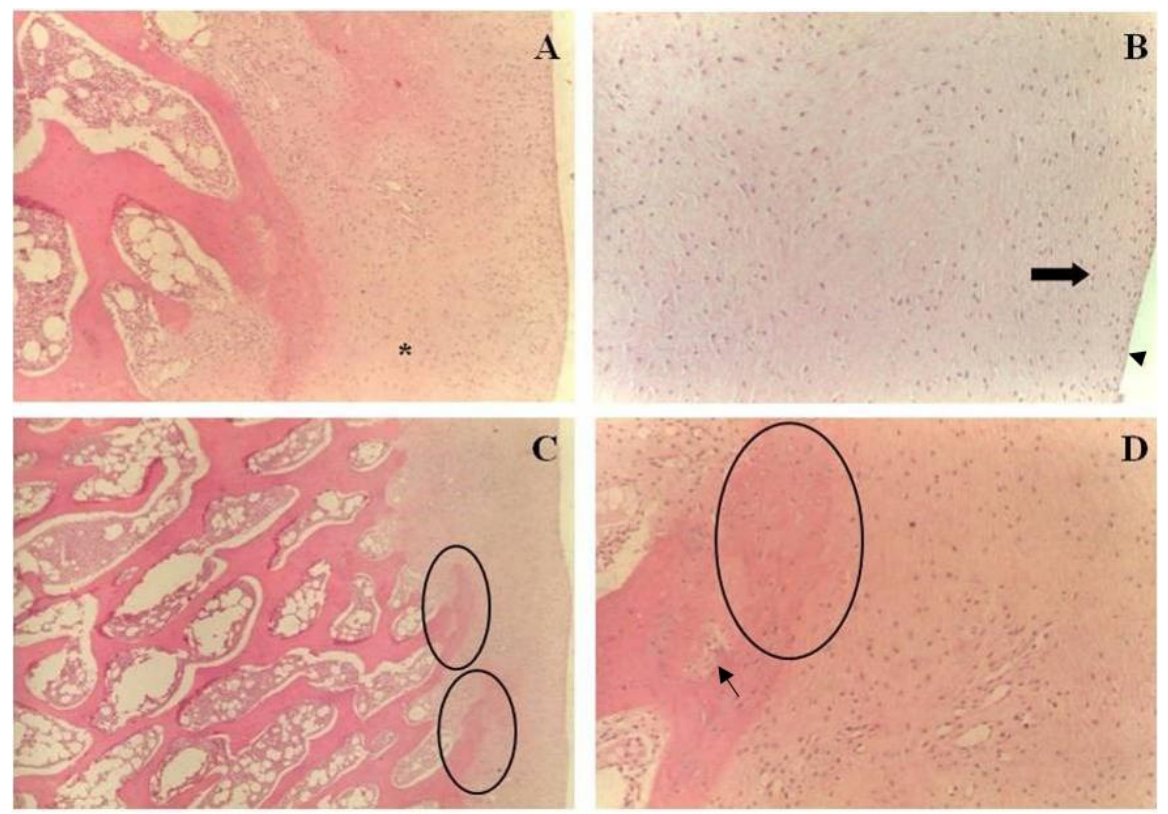

Figure 3. Photomicrographs illustrating repair tissue of osteochondral defect in the lateral femoral condyle in a dog at the end of T30. (A) Presence of fibrocartilage (*), H\&E, 100x. (B) Higher magnification of fibrocartilaginous tissue demonstrated in A, showing chondrocytes (arrow) displayed parallel to articular surface (arrowhead), H\&E, 200x. (C) Subchondral bone formation (circles) at the deepest defect region, H\&E, 40x. (D) Higher magnification of subcondral bone neoformation process (circle) in the region near blood vessels (arrow), H\&E, 200x.
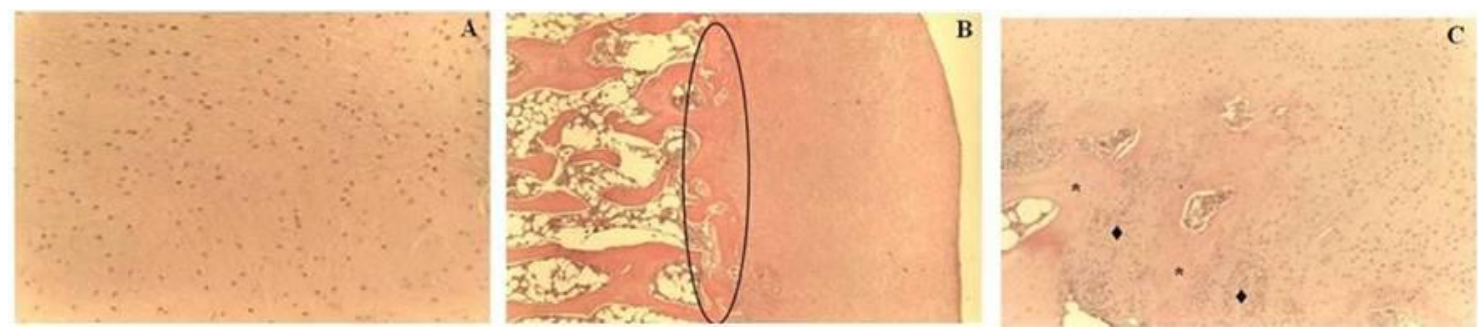

Figure 4. Photomicrographs illustrating repair tissue of osteochondral defect in lateral femoral condyle of a dog at the end of T90. (A) Repair tissue constituted of fibrocartilage, H\&E, 200x. (B) Continuous subchondral bone formation (circulated area), H\&E, 40x. (C) Presence of ossification regions ( $\diamond)$ diffuse in already new bone tissue $(*), H \& E, 100 x$.
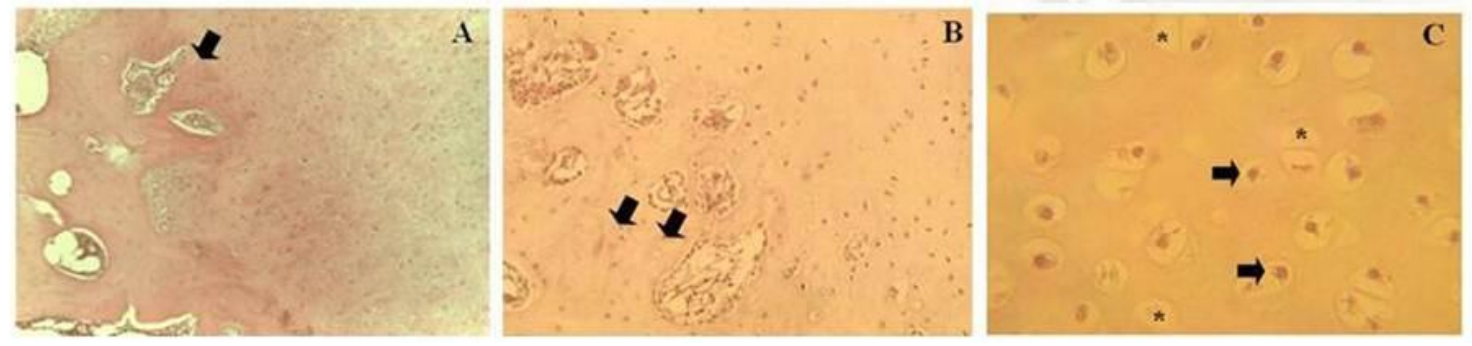

Figure 5. Photomicrographs illustrating repair tissue of osteochondral defect in lateral femoral condyle of a dog at the end of T90. (A) Discontinuity of calcification line (arrow), H\&E, 100x. (B) Presence of large and round nucleated cells (chondrocytes, arrows) in the trabecular region, H\&E, 200x. (C) Region with hyaline cell features. Note the presence of nuclear pyknosis of chondrocytes (arrows) and empty lacunae (*), H\&E, 400x. 


\section{DISCUSSION}

The macroscopic findings of osteochondral defects from both groups at the end of T15 are in agreement with the report of Souza et al. (2000), who noticed partial filling of defect by reddishpinkish repair tissue at 15 days after injury induction in the trochlear sulcus in rabbits. At 30 postoperative days (T30), partial filling by white-color tissue did not correspond to that found by Hurtig et al. (1988), who reported that, when similar injuries were induced in the wrist of equines, there were few alterations at 30 postoperative days. However, at 30 days after osteochondral injury induction in rabbits, Kim et al. (1991); Shapiro et al. (1993) and Souza et al. (2001) noted complete filling of the injured area. The discrepancies between reports suggest that the repair process of osteochondral defects can vary according to the animal species adopted as an experimental model.

Further studies with longer treatment time and more accurate tissue repair mensuration techniques are necessary to affirm that the treatment with chondroitin and glucosamine sulfate influenced the macroscopic filling pattern of defects, as in T60 the tissue developed up to the articular surface level only in one CG animal, while in T90 this filling pattern was observed in five TG animals and in two CG animals.

The circular line that delimited the edges of the repair tissue, which was present even in cases where there was total defect filling by tissue similar to hyaline and which corresponded to the punch diameter used in the defect creation, corroborates the findings of Souza et al. (1999). These authors also reported macroscopic evidence of osteochondral injury edges up to seven postoperative weeks, which, according to Wakitani et al. (1994), can be interpreted as a macroscopic sign of continuity absence between adjacent cartilage and repair tissue.

The histological findings of the present study confirmed the reports available in literature, indicating that when the osteochondral defect reaches the trabecular bone, there is, initially, formation of blood clot, which subsequently is substituted by a fibrin net, with capillary proliferation from adjacent bone marrow and mesenchymal cell infiltration in the clot periphery. Superficially, the formation of a fibrous layer occurs with collagen fibers oriented parallel to the articular surface, and more deeply, mesenchymal cells are differentiated in chondroblasts. As cellular differentiation occurs, the repair tissue shows frequent fibrocartilage aspect and, at the deepest repair tissue region, new subchondral bone formation occurs. Such findings are in agreement with reports of Mitchel and Shepard (1976); Hurtig et al. (1988); French et al. (1989); Shamis et al. (1989); Kim et al. (1991), Shapiro et al. (1993); Souza et al. (1999); Souza et al. (2000), who still mention that tissue architecture regeneration of articular surface is a rare event, occurring in a reduced number of osteochondral defects, a fact confirmed in this study, as there was no hyaline architecture restoration in any of the 48 animals used.

Adherence of the membrane synovial observed in one TG animal from T60 was also reported in studies on osteochondral defect repair in rabbits carried out by Souza et al. (2001) and Filgueiras (2008), who mentioned that this finding is related to the membrane projection over the injury aiming at recovering the surface and allowing that mesenchymal cells invade the tissue, promoting the repair.

The results obtained by histomorphometric analysis indicated that the difference observed in mean percentage values of chondrocytes between TG and CG of T30 possibly happened at random, as if the nutraceutical administration were related to the reduction in the number of chondrocytes, it is supposed that this would repeat in T60 and T90. The difference verified in the histomorphometric analysis between T60 groups, regarding the area of new subchondral bone formation, contrasts with the conclusion of Guarnieiro et al. (2007), who did not observe mineral density increase during the repair of fractures in mice treated with chondroitin and glucosamine sulfate. Although Guarnieiro et al. (2007) have induced a fracture in the middle third of the tibia, outside articular environment, the comparison between the two studies is still relevant, since the osteochondral defect in the present study reached the trabecular bone, allowing subchondral bone repair intermediated by blood supply from this trabecular bone (Steadman et al., 2001), which also participates in the processes of repair and mineral deposition 
of cortical bone fractures reparation (Dallas, 1951).

Although studies have confirmed that parenteral administration of chondroitin sulfate stimulates chondrocytes metabolism and satisfactorily reduces the progression of articular cartilage degeneration in DAD models induced by chronic instability in dog knee (Gonçalves et al., 2008; Melo et al., 2008), the results of the present study clarify that the chondroitin sulfate in association with glucosamine, as a nutraceutical, did not promote the same stimulus in the repair of sharply induced osteochondral defects.

Such finding supports the assumption of Herontin et al. (2005), that beneficial effects should not be extended to any chondroprotective formulation, given that the methodology of scientific studies available in the literature are different, mainly regarding concentration and dosage of substances, therefore there is no common profile on the composition, pharmacokynetics and pharmacodynamics between products formulated both for experimental and commercial purposes. Thus, there are many chondroprotective nutraceutic options on the market and, although chondroitin and glucosamine sulfate concentrations can be standardized during the production of a certain laboratory, when we compare the product from a brand with the product from another brand we can find divergences both in the concentration tablets as in the dosage stated on the label. These divergences, combined with the non-recognition of this product category called chondroprotective by Food and Drug Administration and the absence of a standardized dosage which actually proves its effectiveness (US Food and Drug Administration, 2004), justify the controversy regarding its use and incite caution from veterinarians to prescribe them, and the professionals are also responsible for alerting the owner that the effectiveness of these products is highly questionable in the scientific scope.

\section{CONCLUSION}

It is concluded that nutraceutical, at the concentration, dosage and administration period adopted in this study, did not significantly influence the repair of experimentally induced osteonchondal injuries.

\section{ACKNOWLEDGEMENTS}

The authors thank professors Eliane Gonçalves de Melo and Rogéria Serakides, from the Federal University of Minais Gerais, and Marlene Isabel Vargas Vilória, from the Federal University of Viçosa, for helping with histological analyses. To the National Council for Scientific and Technological Development $(\mathrm{CNPq})$ and to the Minas Gerais State Research Foundation (FAPEMIG) for fellowship grants to the authors.

\section{REFERENCES}

ARAFA, N.M.S.; HAMUDA, H.M.; MELEK, S.T. et al. The effectiveness of Echinacea extract or composite glucosamine, chondroitin and methyl sulfonyl methane supplements on acute and chronic rheumatoid arthritis rat model. Toxicol. Ind. Health., v.29, p.187-201, 2013.

BIASI, F.; RAHAL, S.C.; VOLPI, R.S. et al. Reconstrução do ligamento cruzado em cães, associado ou não ao sulfato de chondroitin. Arq. Bras. Med. Vet. Zootec., v.57, p.442-447, 2005.

BLITTERSWIJK, W.J.; NES, J.C.M.; WUISMAN, P.I.J.M. Glucosamine and chondroitin sulfate supplementation to treat symptomatic disc degeneration: Biochemical rationale and case report. BMC Complement. Altern. Med., 2003. Disponível em: 〈http://www.biomedcentral.com/1472-6882/3/2〉. Acessado em: 7 set. 2009.

CLARK, D.M. Current concepts in the treatment of degenerative joint disease. Comp. Cont. Educ. Pract. Vet., v.13, p.1439-1446, 1991.

DALLAS, B.P. Biologic principles in the healing of fractures and their bearing on treatment. Ann. Surg., v.133, p.433-446, 1951.

ELEOTÉRIO, R.B.; BORGES, A.P.B.; PONTES, K.C.S. et al. Glucosamine and chondroitin sulfate in the repair of osteochondral defects in dogs - clinicalradiographic analysis. Rev. Ceres, v.59, p.587-596, 2012.

FILGUEIRAS, R.R. Uso de condrócitos heterólogos cultivados na reparação de falhas osteocondrais produzidas no joelho de cães. 68f. 2008. Tese (Doutorado em Medicina Veterinária) - Universidade Federal de Viçosa, Viçosa.

FRENCH, D.A.; BARBER, S.M.; LEACH, D.H. et al. The effect of exercise on the lealing of articular cartilage defects in the equine carpus. Vet. Surg., v.18, p.312-321, 1989. 
GONÇALVES, G.; GOMES, M.G.; NUNES, V.A. et al. Effect of chondroitin sulfate and sodium hyaluronate on chondrocytes and extracelluar matrix of articular cartilage in dogs with degenerative joint disease. Arq. Bras. Med. Vet. Zootec., v.60, p.93-102, 2008.

GUARNIEIRO, R.; MOLIN, E.D.; VAZ, C.E.S. et al. Avaliação do efeito da glicosamina e chondroitin na consolidação de fratura: estudo experimental em ratos. Rev. Bras. Ortopedia, v.42, p.201-205, 2007.

HALL, A.H. Effectiveness of glucosamine and chondroitin for osteoarthritis. Am. Fam. Physician, v.86, p.994-998, 2012.

HERONTIN, Y.; SANCHEZ, C.; BALLIGAND, M. Pharmaceutical and nutraceutical management of canine osteoarthritis: present and future perspectives. Vet. J., v.170, p.113-123, 2005.

HURTIG, E.A.; FRETZ, P.B.; DOIGE, P.B. et al. Effects of lesion size and location on equine articular cartilage repair. Can. J. Vet. Res., v.52, p.137-146, 1988.

KANZAKI, N.; SAITO, K.; MAEDA, K. et al. Effect of a dietary supplement containing glucosamine hydrochloride, chondroitin sulfate and quercetin glycosides on symptomatic knee osteoarthritis: a randomized, double-blind, placebo-controlled study. $J$. Sci. Food Agric., v.92, p.862-869, 2012.

KIM, H.K.; MORAN, M.E.; SALTER, R.B. The potential for regeneration of articular cartilage in defects created by chondral shaving and subchondral abrasion: an experimental investigation in rabbits. $J$. Bone Joint Surg., v.73, p.1301-1315, 1991.

MELO, E.G.; NUNES, V.A.; REZENDE, C.M.F. et al. Sulfato de chondroitin e hialuronato de sódio no tratamento da doença articular degenerativa em cães: estudo histológico da cartilagem articular e membrana sinovial. Arq. Bras. Med. Vet. Zootec., v.60, p.83-92, 2008.

MILLER, K.L.; CLEGG, D.O. Glucosamine and chondroitin sulfate. Rheum. Dis. Clin. N. Am., v.37, p.103-118, 2011.

NAKASONE, Y.; WATAE, K.; WATANABE, K. et al. Effect of a glucosamine-based combination supplement containing chondroitin sulfate and antioxidant micronutrients in subjects with symptomatic knee osteoarthritis: A pilot study. Exp. Ther. Med., v.2, p.893-899, 2011.

SAWITZKE, A.D.; SHI, H.; FINCO, M.F. et al. Clinical efficacy and safety of glucosamine, chondroitin sulfate, their combination, celecoxib or placebo taken to treat osteoarthritis of the knee: 2 -yer results from GAIT. Ann. Rheum. Dis., v.69, p.14591464, 2010.
SHAMIS, L.D.; BRAMLAGE, L.R.; GABEL, A.A. et al. Effect of subchondral drilling on repair of partialthickness cartilage defects of third carpal bones in horses. Am. J. Vet. Res., v.50, p.290-295, 1989.

SHAPIRO, F.; KOIDE, S.; GLIMCHER, M.J. Cell origin and differentiation in the repair of full-thickness defects of articular cartilage. J. Bone Joint Surg., v.75, p.532-553, 1993.

SINUSAS, K. Osteoarthritis: diagnosis and treatment. Am. Fam. Physician, v.85, p.49-56, 2012.

SOUZA, R.L.; RAISER, A.; GUIMARÃES, L. et al. Precursores de glicosaminoglicanos na reparação articular após trauma iatrogênico em joelhos de cães. Clín. Vet., v.23, p.33-38, 1999.

SOUZA, T.D.; CARLO, R.J.; VILÓRIA, M.I.V. Avaliação histológica do processo de reparação da superfície articular de coelhos. Cienc. Rural, v.30, p.439-444, 2000.

SOUZA, T.D.; CARLO, R.J.; VILÓRIA, M.I.V. Electrotherapy on the healing process in the articular surface of rabbits. Cienc. Rural, v.30, p.439-444, 2001.

STEADMAN, J.R.; RODKEY, W.G.; RODRIGO, J.J. Microfracture: surgical technique and rehabilitation to treat chondral defects. Clin. Orthop. Relat. Res., v.391, p.S362-S369, 2001.

US FOOD AND DRUG ADMINISTRATION. Letter regarding the relationship between the consumption of glucosamine and/or chondroitin sulfate and a reduced risk of: osteoarthritis, osteoarthritis-related joint pain, joint tenderness, and joint swelling; joint degeneration; and cartilage deterioration. Reston, 2004. Disponível em: <http://www.fda.gov/food/ingredientspackaginglabeli ng/labelingnutrition/ucm073400.htm>. Acessado em: 27 jun. 2014.

VAUGHAN-SCOTT, T.; TAYLOR, J.H. The pathophysiology and medical management of canine osteoarthritis. J. South Afr. Vet. Assoc., v.68, p.21-25, 1997.

WAKITANI, S.; GOTO, T.; PINEDA, S.J. et al. Mesenchymal cell-based repair of large, full-thickness defects of articular cartilage. J. Bone Joint Surg., v.76, p.579-592, 1994.

WANDEL, S.; JÜNI, P.; TENDAL, B. et al. Effects of glucosamine, chondroitin, or placebo in patients with osteoarthritis of hip or knee: network meta-analysis. Brit. Med. J., v.341, p.1-9, 2010. 